\title{
Should a flora account be taken for granted? A fresh look at Polyscias serratifolia (Araliaceae)
}

\author{
$\uparrow$ D.G. Frodin \\ Royal Botanic Gardens, Kew, \\ Richmond, Surrey TW9 3AE
}

\begin{abstract}
Polyscias serratifolia (Miq.) Lowry \& G.M.Plunkett (Gastonia serratifolia (Miq.) Philipson) currently encompasses a range of small to large trees endemic to Malesia save for two localities in the Solomon Islands. Latterly it has been referred to Polyscias subgen. Tetraplasandra but, lacking genomic analyses, only by assumed association with Polyscias spectabilis (Harms) Lowry \& G.M.Plunkett. Nothing should, however, be taken for granted: collections accounted for since 1979, notably from 'Wallacean' Malesia, suggest that Polyscias serratifolia s.l. is a cluster of species, some previously described. From a total of 100 records and utilising both specimens and digital images I examined several likely diagnostic morphological characters, some not before used, and show that these taxa represent varying, but distinguishable, combinations of their states. Hopefully this will lead to additional field studies and collections including material for genomic analyses. Many of these taxa have not been recollected for decades or even a century or more. As a first step towards a revision, evaluations of the existing published taxa are presented, and for all eight new combinations are made or revived (Tetraplasandra koordersii Harms, Gastonia papuana Miq., Tetraplasandra paucidens Miq., T. philippinensis Merr., and T. solomonensis Philipson along with the imperfectly known Gastonia eupteronoides Teijsm. \& Binn., Polyscias serratifolia proper, and Gastonia winkleri Harms).
\end{abstract}

Keywords. Biogeography, Gastonia serratifolia, Malesia, morphology, species limits, taxonomy

\section{Introduction}

The subject of this paper, the glabrous, imparipinnately-leaved treelets or small to moderately large trees in the Araliaceae currently known as Polyscias serratifolia (Miq.) Lowry \& G.M.Plunkett (Lowry \& Plunkett, 2010) but recently as Gastonia serratifolia (Miq.) Philipson (Philipson, 1979b), is notable for its wide distribution over most of Greater Malesia but seeming relative infrequency (Philipson, 1970b, 1979a). Further distinctive features include the sparse branching, the often thick twigs with the leaves more or less in rosettes at their ends and, moreover, in their arrangement featuring a considerable range of Fibonacci fractions, the entire to coarsely serrate leaflets, the terminal inflorescences most commonly with an extended main axis and pseudo-verticillate branching, the flowers ultimately in umbellules and usually anisomerous with 5-9 petals, up to 55 stamens and 6-12 ovary-locules, and inferior globose fruit with variously developed but often radiating stylar arms flush 
with or arching just above the calyx-rim. In Sundaic Malesia as well as Palawan in the Philippines, Polyscias serratifolia has usually been collected along shorelines or on small islands up to no great elevation, but in the 'Wallacean' biogeographical zone as well as the Bird's Head Peninsula of New Guinea and nearby islands examples have, in addition to shorelines, coastal areas and islands, also been obtained inland at altitudes of up to $1600 \mathrm{~m}$ (though not in the interior of the Peninsula, where the putatively related P. spectabilis (Harms) Lowry \& G.M.Plunkett is to be found). To the east, it has been twice collected in the northern piedmont of the Nassau Range of the central cordillera of New Guinea and, more than a thousand kilometres beyond, in the Solomon Islands where, in addition to a single occurrence on the at least partly ultramafic San Jorge Island off Mahaga (Santa Isabel), a distinctive form occurs at up to $900 \mathrm{~m}$ on Makira (San Cristobal).

Prior to its transfer to Polyscias, $P$. serratifolia was a member of the Madagascan-Mascarene-Seychellean-Malesian genus Gastonia Comm. ex Lam. described in 1786 (for its 'classical' distribution, see Roos, 1984: map 255). The firstknown of the currently included species, Arthrophyllum serratifolium, was described in 1861 by Miquel from material obtained from the Indian Ocean coast of what is now North Sumatra by H. Diepenhorst. It was soon followed by Gastonia papuana Miq. and Tetraplasandra paucidens Miq., both described in 1863, and Gastonia eupteronoides Teijsm. \& Binn., also in 1863 but only from cultivation and very soon reduced by Miquel to T. paucidens. Later additions encompassed Tetraplasandra koordersii Harms in 1904 from northeast Sulawesi, T. philippinensis Merr. in 1906 from Palawan, Gastonia winkleri Harms in 1917 from the Makassar Strait side of Borneo, and T. solomonensis Philipson in 1951 from the eastern Solomon Islands (publication details appear below under 'Taxonomy'). All these were reduced to a single, variable species by Philipson, firstly as Gastonia papuana (Philipson, 1970b: 492) and then, on the transfer of Arthrophyllum serratifolium, G. serratifolia (Philipson, 1979a: 68) - although with a hint that 'local subspecies' might be recognisable with more material available for study (Philipson, 1970b: 493). About the same time, Philipson (1970a) conceded that establishing clear generic limits for Gastonia against the other polymerous, pinnately compound-leaved and inarticulately pedicelled genera of Araliaceae might be elusive, although he did separate Gastonia from Tetraplasandra A.Gray primarily on the basis of its radiating stylar arms in maturing fruits - a feature absent or little developed in Tetraplasandra.

Genomic analyses and phylogenetic reconstruction after 2000 of Polyscias and its putative allies, including the work of Costello \& Motley (2007) on the longrecognised, latterly Hawaiian genus Tetraplasandra and its close Pacific allies, Munroidendron and Reynoldsia, resulted ultimately in a drastic alternative approach: the complete reduction, amongst many others, of these genera along with the Asian/ Pacific Arthrophyllum and the whole of Gastonia s.s., to an enlarged Polyscias (Plunkett \& Lowry, 2010). Eleven subgenera were formally recognised (Lowry \& Plunkett, 2010). Polyscias serratifolia was, together with the already-mentioned (and, at up to $45 \mathrm{~m}$, a giant amongst the Araliaceae) P. spectabilis — beyond the Bird's 
Head Peninsula found also throughout the rest of New Guinea and, into the Pacific, in New Ireland and the southern Solomon Islands - accommodated in subgenus Tetraplasandra (A.Gray) Lowry \& G.M.Plunkett. Towards the current infrageneric classification, Polyscias spectabilis was genomically sampled and included in the analyses of, initially, Costello \& Motley (2007) and then Plunkett \& Lowry (2010), but $P$. serratifolia was not.

\section{Investigations}

Philipson (1970b: 493) had already remarked of what was then Gastonia papuana that 'the variation within New Guinea is as great as over the remainder of its range'. I had a first chance to follow that up not long after my arrival in 1971 at the University of Papua New Guinea in Port Moresby. On a trip to the Division of Botany herbarium in Lae, I took the opportunity to study other members of the Araliaceae as well as my primary interest, Schefflera. As the majority of the Papuasian and Solomons collections seen by Philipson and included in Gastonia papuana were represented there by replicates, I was able to evaluate this opinion and draw my own inferences. Study trips to Bogor in 1978 and 1991 as well as at various times to Leiden enabled me to examine an increased range of material encompassing Indonesia and other parts of Malesia, including a number of types. This led to a conviction, reinforced by collections made after 1979 as well as others not by then accounted for, that Philipson's circumscription might have been too wide - and that at least some segregation might be desirable if only to focus closer attention to the apparently rare and very scattered populations and hopefully to find others.

More active investigations were commenced at Kew after 2010, utilising available holdings but also taking advantage of the advent after 2012 of specimen images (other than types) of the holdings at Leiden and, just prior to the 9th Flora Malesiana Symposium, a further review of those at Bogor (now at Cibinong). The holdings of MNHN, Paris, the great majority digitised over 2010-2012, were also checked (and revealed two pre-1840 collections never previously documented and unrepresented elsewhere). Where no formal resource existed, digital images were made of the available collections (notably at Kew and Cibinong near Bogor but also in Singapore, Kuching and Sandakan). As good specimens of Polyscias serratifolia are hard to make (and moreover on drying often significantly darken and become brittle), it was advantageous to locate, where possible, more than one replicate of a given number for study. Extensive use was also made of online biodiversity resources. In all, some 100 distinct collections or records, including where available those in support of protologues included within Polyscias serratifolia as delimited by Philipson and also accounting for the 40 records listed in Philipson (1979b) and accepted here, were identified with seven more excluded as not properly included, wrongly determined or indexed, or non-existent (further details are given under 'Results'). 


\section{Results}

Only preliminary results are presented here, but what is clear is that several species can likely be recognised within Polyscias serratifolia s.l. as conceived by Philipson (1979b). While a more precise ultimate number could possibly be worked out from existing material, such might best await further collections in new or previously examined localities - preferably with local sampling as was, for example, carried out during the first half of the 2010s in the vicinity of Weda Bay in Halmahera. No novelties will be described at this time; however, all of the synonymised taxa are, or may be, worth reinstatement - already hinted at for one by Lowry \& Plunkett (2010: 73). The current senior synonym, Arthrophyllum serratifolium, is upheld as Polyscias serratifolia but, having been described from sterile material and with no effectively matching later collections from the same or neighbouring areas, is here viewed, along with two other now long-relegated names, as imperfectly known.

The principal characters used in the past to differentiate species within Polyscias serratifolia s.l. have been leaflet margins, the number of floral parts (petals, stamens and ovary-cells) and their quantitative relationship to one another and, in maturing fruit, the stylopodium and the degree of development of the free portions of the styles. These remain useful but it was found that potential further characters such as phyllotaxis, leaflet venation, detailed inflorescence architecture, and fruit size as well as evidence from ecology — previously not taken up or ignored — could be mobilised.

Amongst previously utilised characters, it was found that there was a greater spread of states than had been acknowledged. Particularly interesting was the degree of stylar development in maturing to mature fruit, where the collections now encompassed by Polyscias serratifolia s.l. featured a wide spectrum of states. These ranged from the boss-like structure traditionally seen as diagnostic for Reynoldsia A.Gray as well as Tetraplasandra [as in, for example, Kostermans \& Wirawan 407 (K, L) from Flores and Lam 3262 (BO, K, L) from Karakelang in the Talaud Islands as well as T. philippinensis] to the radiating stylar arms long associated with Gastonia proper [encompassing, amongst others, G. papuana s.s. as well as de Vogel 4229 (BO, CANB, K, L) from Obi in Maluku, recent collections from Weda Bay including, for example, Tjut Jul Fatisa Bangun 220 (L; field photos at MO) and van Royen 4090 (BO, CANB, K, L, LAE, MAN, SING) from near Sorong in the Bird's Head Peninsula of Indonesian New Guinea, the last figured in Philipson (1979a: 66, fig. 24d)] with the extremes illustrated in Philipson (1970a: 502, figs. 6, 8 and 10). It is possible, however, that at least in herbarium material the styles may have partially disintegrated in the mature fruit from some populations, further obscuring any distinction between 'Gastonia' and 'Tetraplasandra'. Indeed, this may be the case in the just-mentioned van Royen 4090 where, compared with the free styles depicted in the drawing in Philipson (1979a: 66, fig. 24d) — most likely made from the fruits on the L sheet — they have been partly lost in the more advanced fruit of the $\mathrm{K}$ sheet.

Another suite of characters making an impression on me included the not insignificant ranges in stem thickness and phyllotaxis fractions, with the two more or less positively correlated, and leaflet numbers within leaves in the same flush. Almost 
all collections exhibit pachycauly with (when dry) twigs (or stems) usually $1 \mathrm{~cm}$ or more in diameter, spiral leaf arrangement, often stout leaf rachides, and terminal inflorescences with a variously elongate main axis. Phyllotaxis fractions (although not yet quantified) range from relatively low (Tetraplasandra paucidens, exemplified by Lütjeharms 4793 from Enggano off Sumatra) to moderate (as in Phillipson 6427 from the vicinity of Weda Bay) to high (as, for example, in Kostermans \& Wirawan 825 from Wae Mao in west Flores, the already-mentioned Lam 3262, and Tetraplasandra solomonensis in Makira, Solomon Islands).

Also worthy of note are the collections identified with, or superficially similar to, Polyscias serratifolia that always or sometimes have fewer than six carpels and on that character grade into 'classical', non-polycarpous Polyscias. What kept them in the former Gastonia were the apparently inarticulate pedicels along with the supposedly radiating styles. Among these are, once again, Lam 3262 which, moreover, has a 'tetraplasandroid' stylopodium, and Sulit 3855 (PNH 12384) (A, L) from Mt Victoria at $700 \mathrm{~m}$ in Palawan, Philippines, with styles partially united into a discrete column but with distinctly exserted free portions. Both were identified by Philipson as Gastonia papuana s.l. and accordingly listed in Philipson (1979b). However, Sulit 3855 is superficially similar to Edaño PNH 00139 (K, L) from Mt Mantalingahan in Palawan at $4200 \mathrm{ft}$ [1280 m] elevation — included by Philipson (1979b) in his Polyscias borneensis. That, however, has more distinctly acuminate and oblique leaflets and flowers with a stylar column post-anthesis. Nevertheless, the latter may in time partially separate into discrete styles like those in Sulit 3855, and further material may show that no effective distinctions exist. In any case, Edaño PNH 00139 does not in my view fit well with the type collection of Polyscias borneensis (Clemens \& Clemens 32403 [BM, K], Mt Kinabalu, Marai Parai) and should be removed from its circumscription, with that species most likely becoming limited to Borneo. Neither Sulit 3855 (nor, for that matter, Clemens \& Clemens 32403 and Edaño PNH 00139) have distinctly articulate pedicels although possibly an abscission layer develops prior to fruit maturation. Later collections identified as Polyscias serratifolia but not falling properly within the species in Philipson's sense include Argent \& Reynoso 89075 a (L) and 89109 (K, L) from $1300 \mathrm{~m}$ on Sibuyan, Philippines, the latter with a stylar column ending in free portions similar to those in Sulit 3855 (but differing in leaves and leaflets), McDonald \& Ismail 4052 (BISH, BO, CANB, K, L, SING) from the island of Kabaëna off SE Sulawesi at $1200 \mathrm{~m}$ with largely free, radiating styles of the 'Gastonia' type, and Ramos \& Convocar BS 83792 (BO) from Dinagat Island in the southern Philippines, also with 'gastonioid' styles as in McDonald \& Ismail 4052 but differing in the presence of three pseudoverticils of subsidiary umbellules rather than 0-2 as in the Kabaëna plant and, as well, less elongate styles. Along with Sulit 3855 (and possibly in like fashion Edaño PNH 00139), all three occur on more or less isolated insular mountains and, along with other distinguishing features, each is likely to be a new species.

Fruit size is another feature with too great a range effectively to be accommodated in a single species. Tetraplasandra paucidens, Teysmann 11324a.H.B. (L) from Pulau Karimata off west Borneo, and Moll BW 9909 (BO, CANB, L) from Pulau Adi off the 
southern part of the Bomberai Peninsula in New Guinea have, for example, relatively small fruit (not over $5 \mathrm{~mm}$ ); those of the 'gastonioid' de Vogel 4229 (BO, CANB, $\mathrm{K}, \mathrm{L}$ ) from Obi and Phillipson 6427 (L, MO) from Weda Bay, and the somewhat more 'tetraplasandroid' Ary Keim 245 (BO) from Karimunjawa in the Java Sea, are moderately sized (5-6 $\mathrm{mm}$ to 6-7 $\mathrm{mm}$ ); and in T. philippinensis they are at 7-8 $\mathrm{mm}$ long relatively large with similarly-sized fruit also to be seen in, for example, Henderson SF 36272 (K, L, LAE, P, SING) from the Pisang Islands in the Straits of Malacca and Wong 2863 (K, L, SAN) from Bod Gaya off the east coast of Sabah. Strong 'peaks' within this range have, however, not so far been discerned. The larger fruit can have 10 or more pyrenes and may be depressed-globose as, for example, in Curran FB 3809 (K) from Palawan (Tetraplasandra philippinensis) and Kanehira \& Hatusima 13047 (BO, FU) from Waren south of Manokwari in Indonesian New Guinea (the latter first documented by Philipson, 1979b).

Finally, the length of the main inflorescence axis varies considerably, with sometimes hardly any development as, for example, in Eyma 3809 (BO, L, U) and Hendrian et al. 849 (E, L) both from the eastern arm of Sulawesi and so notably less than the minimum of $15 \mathrm{~cm}$ indicated by Philipson (1970b: 493), while lengths of $>25 \mathrm{~cm}$ have also been seen, as in Docters van Leeuwen 10342 (BO) from the Tariku basin in the already-mentioned Nassau Range of New Guinea or the previously-noted Henderson SF 36272.

\section{Discussion}

The recognition that Polyscias serratifolia s.l. as currently delimited represents a suite of variously discrete taxa not only sheds some light on potential limits within what was an imperfectly understood assemblage. Given in particular the range of states shown by the stylopodium and style development in maturing to ripe fruits (and potential stylar disintegration by maturation), it also highlights the limitations of recognising distinct genera amongst the imparipinnately-leaved, non-articulate, and polymerous Araliaceae (Lowry \& Plunkett, 2010). The revived or putatively new species are best delineated by unique combinations of characters (Wheeler \& Platnick, 2000; Forey, 2005). With investigations at best at a rudimentary level, a 'classical' morphological species concept (Zachos, 2016: 90, and references there cited) is all that can be adopted for the cluster of taxa associated with Polyscias serratifolia s.l.

Since 1979, the majority of additional collections have been made in 'Wallacea', notably in Sulawesi and central and northern Maluku, with the first records for Halmahera gathered only in the second decade of the twenty-first century. In Sunda, additional records of Polyscias serratifolia s.l. have been obtained from the islands in the South China Sea off Sarawak and Sabah and, allied to these, the above-mentioned Ary Keim 245, for Karimunjawa a first record. The likewise already-mentioned Wong 2863 from Bod Gaya, again a new locality, was found to be not unlike Tetraplasandra philippinensis, more so than were plants from the west coast of Sabah. Technical and scholarly re-evaluation of the records was also undertaken with, for example, the first 
collection from Sangiang Island considered to have most likely been made by van Hasselt rather than Forsten, and 'Teysmann 615' of Philipson (1979b: 1115) being identified in Bogor actually as Teysmann 6015.H.B. The latter was in addition found not to have come from 'Siam' as given on the label but more likely was obtained on Bintang in the Riau group near Singapore in 1862 during a stopover to or from what is now Thailand (Van Steenis-Kruseman, 1950).

The greater apparent presence of, and diversity within, Polyscias serratifolia s.1. in 'Wallacea' (and northwestern New Guinea) in contrast to Sunda is in my view best explained by the relative absence, for historical reasons, of dipterocarp competition (only six species from that family currently being known from Sulawesi) and the greater incidence of ultramafic areas, also limiting for many plants but, apparently, not P. serratifolia. As already noted, in Sunda Polyscias serratifolia s.l. is found nearly exclusively on small islands, though also including the somewhat larger but dipterocarpfree Enggano (there reaching its largest recorded height of $27 \mathrm{~m}$ and diameter of 0.35 $\mathrm{m})$. Loss of natural vegetation, particularly in Java, may also be a factor, but ultimately an explanation might be palaeohistorical (cf. Morley, 2000) or ecological. The currently known overall distribution of Polyscias serratifolia s.l. shows some similarities with P. nodosa (in a neighbouring but distinct clade of Polyscias s.l. and distinguished by the small flowers in numerous, racemosely arranged, few-flowered heads and leaves always with more numerous pinnae), but while $P$. nodosa - a fast-growing secondary tree species notably characteristic, like $P$. serratifolia s.1., of 'Wallacea' and the Philippines — is well-represented in Java (though rare to absent in 'core' Sunda), P. serratifolia s.l. occurs only on nearby offshore islands including Sangiang in the Sunda Strait and Bawean as well as the already-mentioned Karimunjawa in the Java Sea. In Sunda beyond Java, as well as within Java and in the Philippines, the ecological role in particular of the widespread Polyscias jackiana s.l. (including P. diversifolia s.1. and the sometimes segregated Arthrophyllum javanicum, the latter with twice-compound principal leaves), usually found in secondary vegetation, needs further study; nevertheless it seems more adapted to prevailing edaphic factors and competition than are $P$. serratifolia s.1. or $P$. nodosa. By contrast, populations of Polyscias serratifolia s.1. might be more moisture-dependent, placing it at a potential disadvantage in, for example, the 'subxerophilic' potential natural vegetation of welldrained ground in lowland Borneo (Winkler, 1914).

In New Guinea, Polyscias serratifolia s.l. east of Cendrawasih Bay is almost completely replaced by $P$. spectabilis, a medium to large tree of the lowlands to mid-elevations with conspicuous, pinnately compound leaves and large, depressedglobose fruit $8 \mathrm{~mm}$ in height by $10 \mathrm{~mm}$ in diameter with 10-22 styles (15 in figure 6 in Philipson, 1970a: 502). Only in the Bird's Head Peninsula does Polyscias spectabilis overlap with $P$. serratifolia, with the former usually found inland. Beyond New Guinea, as presently understood Polyscias spectabilis extends to a few localities in northeast Queensland (Hyland et al., 2003) as well as New Ireland (where it readily regenerates) and the southern Solomon Islands (where in a few localities there is once more overlap with $P$. serratifolia s.1.). One of the four known occurrences of Polyscias serratifolia in the Solomons, on the ultramafic San Jorge off Santa Ysabel (Corner RSS 2695), is very 
similar to plants on Biak Island in Cendrawasih Bay, Papua Barat (Versteegh \& Vink $B W$ 8282); the other three are part of what was initially described as Tetraplasandra solomonensis, endemic to Makira (San Cristobal) and, as previously indicated, notable for its high phyllotaxis.

No published analyses based on gene sequences yet exist for Polyscias serratifolia s.1., either within or amongst its populations or in comparison with likely related species such as $P$. spectabilis. Analyses of extracts from preserved material of Polyscias serratifolia, including Lütjeharms 4793, by Costello \& Motley (2007) were unsuccessful, while recent material from Weda Bay has yet to be accounted for. Nevertheless, given the material now available as well as the introduction of new characters, from a morphological, ecological and geographical point of view the retention of Polyscias serratifolia s.l. is not justified although some character suites have to be studied in more detail than has so far been possible. Above all, further collections, images and field data are essential (cf. Ehrlich, 2005) - 'desk science' having for now reached a plateau.

New combinations, where necessary and the taxa concerned at least moderately understood, are therefore made within Polyscias for four of the seven synonyms under P. serratifolia in Philipson (1979a), and one further - Polyscias papuana (Miq.) Seem. - revived, with typifications where possible and discussion. Three further taxa, including Polyscias serratifolia in a strict sense, also belong to Polyscias in its current sense and are likewise enumerated but are viewed as imperfectly known.

Finally, while it fairly can be said that the material seen by 1979 was limited, particularly so at the time of Philipson's initial papers (Philipson, 1970a,1970b), the impression gained was that he might have been more interested in larger-scale character ranges and what might be useful towards generic delimitation. At species level and with a flora account in mind, he took a broad view, not moving on even with the further material annotated by 1979, perhaps given he also needed to work up other genera including the relatively sizeable Osmoxylon and Polyscias. He may also have been influenced by the approaches to species taken in Flora Malesiana (Van Steenis, 1957; for a countervailing view, see Smith, 1978, 1979). By contrast, in more recent decades previous relatively broad circumscriptions for many Malesian plants have been challenged as a result of new material, approaches, and research, for example in Hemerocallidaceae (Carr, 2006), Fagraea (now in Gentianaceae; Wong \& Sugau, 1996), and Ceriops in Rhizophoraceae (Ballment et al., 1988; Sheue et al., 2009). Polyscias serratifolia s.l. likely is no different.

\section{Materials}

The starting points for this study were the taxonomic treatments by Philipson (1970a, 1970b, 1979a) and list of specimens seen with identifications (Philipson, 1979b) along with notes on collections seen in herbaria, particularly in Papua New Guinea and Australia. To these were added, particularly after 2009 and from as many sources as possible, the many collections made since 1979 along with older collections either without number (editorially excluded from Philipson, 1979b) or not otherwise studied. 
These investigations ultimately yielded 100 records, or 'collection events', with, for the great majority, one or more images also acquired, either made for this research (particularly at Bogor and Kew) or downloaded from providers (notably Naturalis, Leiden). An additional seven records were excluded on account of presumed clerical or identification errors in Philipson (1979b) or because they did not belong to Polyscias serratifolia s.1., with a single exception (Lam 3262) viewed here as having six or more stigmata, styles or pyrenes. The current figure contrasts favourably with the 25 for Malesia (26 also accounting for the Solomon Islands) seen by Philipson (1970b) and the 40 (as corrected from a raw total of 43) listed in Philipson (1979b), to which can be added four from the Solomons available by the late 1970s so yielding a total of 44 .

Of the 100 records, seven are from the 'Steenisian' units of Malaya, Sumatra and Java, 14 from Borneo, 24 from Sulawesi (including one each from Kabaëna and the Talaud Islands), six from the Philippines (entirely from Balabac and Palawan), 19 from Maluku (including 12 from recent botanical exploration of the Weda Bay area in Halmahera but none from Maluku Tenggara), 11 from Nusa Tenggara and Timor (including seven from Flores), 14 from New Guinea, four from the extra-Steenisian Solomons, and one (Gastonia eupteronoides) described only from cultivation. Two of these, both types, are either not extant or without known authentic preserved material.

The materials utilised comprise standard herbarium specimens; only a few related field images have also become available. Of these specimens, the majority (66) are now in Naturalis (Leiden, the Netherlands) with all also recorded through GBIF (including duplicates, 105 occurrences from the May 2019 total of 160; GBIF, 2019), but substantial numbers are, or are also, in BO (45) and K (39). Smaller ranges are in A, BISH, BRI, BZF, C ['Noona Dan' expedition], CANB, E, F [Palawan], KEP, LAE, MAN, MO [Weda Bay investigations], NY, P, SAN, SAR, SING and US but none has more than 12. Relatively few collections have more than three replicates, and several appear to be unicates (among them two from Hombron in P, never previously accounted for). Most specimens are to varying degrees imperfect, and particularly uncommon are whole main axes of inflorescences where these are likely to be present. Field images remain few. As elsewhere in Araliaceae, the presence of maturing to mature fruit is helpful.

\section{Methods}

The list of identifications (Philipson, 1979b) was the only published source for collections seen by Philipson subsequent to the citations in his revision of Malesian Gastonia (Philipson, 1970b). Early in the 2000s, I scanned and digitised the contents of that list into the form of a *.CSV file, which then became the basis for an *.XLS file suitable for translation into Brahms as an RDE (Rapid Data Entry) file. Missing data for Polyscias serratifolia s.1. were then added from the collections in K and elsewhere as individual specimens in the list were located. The four known relevant collections from the Solomon Islands (not in Philipson, 1979b) were also incorporated as well as those from Malesia without number (for editorial reasons not in the Identification 
Lists). For completeness, Winkler 3078 from Paser Regency in Kalimantan Timur, the basis for Gastonia winkleri Harms, was also added although no material had been available to Philipson, the holotype at B having been destroyed and the status of any counterpart at WRSL (where Winkler had been until 1941 on the academic staff) not known. As the great majority of the records lacked coordinates, I also retrospectively georeferenced them as far as possible and as resources permitted, yielding a distribution map broadly similar to that of Philipson (1979b) but with more points. Digital images, from late in the 2000s more widely available, were also utilised for comparisons along with physical specimens. The images were made or downloaded largely in 2012-13 and now cover the majority of known gatherings. Where no publicly available sources were available, I made medium- or high-resolution images or scans at Kew, Bogor (Cibinong), Singapore and Sandakan (Sepilok), adding to these old photographs of Kanehira \& Hatusima 13047 made at Kyushu University (FU) in the 1960s. Detailed images in particular of fruits where available were also made. An extensive set of annotated image files has now been assembled for future reference, which facilitates relatively rapid comparisons.

'Classical' comparative observations of specimens and images were made, and the results organised into putatively distinct taxa. As already indicated, Polyscias serratifolia s.l. as a whole was delimited on the basis primarily of stylar and carpel number, using as a guideline the ' $6-12$ ' cells of Philipson (1970b: 493) along with the absence of an articulation at the base of the cupule in flower. One outcome was that there was little evident gross difference between species conventionally included in Polyscias, such as P. borneensis (and in particular its somewhat distinct Palawan record, Edaño PNH 00139), P. belensis s.l. in New Guinea, and the members of $P$. serratifolia s.1. with relatively few (6-7) stigmata and pyrenes and lacking a marked development of stylar arms. It may be noted, though, that both Polyscias borneensis in Borneo and P. belensis in New Guinea are elevationally or otherwise in marginal situations - much as appears to be the case with most of the elements of $P$. serratifolia s.l.

For discovery or confirmation of occurrence records as well as character analyses, extensive use was made of the online Global Biodiversity Information Facility (GBIF) and other resources (including individual provider's sites), but they have to be viewed as an addition to, not a substitute for, conventional approaches (cf. Beck et al., 2013; Gaiji et al., 2013). As is well recognised, many physical resources, a number of them quite significant, have still effectively to be 'mobilised' including some essential towards the study of insular Southeast Asian plants. In addition, a not inconsiderable number of specimen images have still to be added to currently included records - necessary where identifications may be in doubt or for locating replicates of better quality, particularly where for a given record such may be few (and for a given group no full set of published citations is to hand through a revision or other outlets). The identification of occurrences is made easier where in published revisions or critical notes records have been fully cited (cf. Meier \& Dikow, 2004); unfortunately, that has not always been the case. 


\section{Taxonomy}

As this is but a first contribution to a re-study of Polyscias serratifolia s.1., no effort is made to describe new species. The existing, currently synonymous taxa are, however, considered, and new combinations in Polyscias made where available evidence seems favourable to their good standing as well as in two cases which nevertheless remain imperfectly known.

\section{New or existing combinations in Polyscias J.R.Forst. \& G.Forst.}

1. Polyscias koordersii (Harms) Frodin, comb. nov. - Tetraplasandra koordersii Harms, Ann. Jard. Bot. Buitenzorg 19: 12 (1904); Harms, Icon. Bog. 2: pl. 178 (1906). [- Tetraplasandra paucidens auct. non Miq.: Koorders, Minahassa: 488 (1898)]. TYPE: [Indonesia, Sulawesi], Minahassa, Koorders 16102 (lectotype BO [current acc. nos. 1830633, 1830634 - i.e. a single specimen over 2 sheets], designated here).

Tetraplasandra koordersii was based on two collections from Minahassa in Sulawesi, Koorders 16102 and 16103 (current acc. no. 1830635), both only in Herbarium Bogoriense (BO). Though remounted, the material is not in good condition and in particular representation of the inflorescence is imperfect. Distinctive features include the comparatively numerous, notably acute, and at least sometimes broadly but shallowly crenulate leaflets (as illustrated in Icones Bogorienses, but the crenulations as depicted therein are too marked for fully adult foliage). Additional material in BO and elsewhere suggests, however, that the species may be widespread in Sulawesi: potential records include Eyma 3809 (BO, L, U) and Uji et al. 5015 SPSE (BO), both from Luwuk, Kjellberg 1828 (BO, S) from Tujambu west of Palopo, Teijsmann 13687 H.B. (BO; also in L, without number) from Lompobatang, and the poorly preserved Meijer 9452 (BO) from Nokilalaki. Amongst these are more complete reproductive structures than were available to Koorders, but the detail given in his illustration is congruent with the umbellular rays and flowers represented in these numbers, particularly Eyma 3809 and Teijsmann 13687 H.B. The inflorescences are as a whole sub-compound-umbellate, with a significant main axis wanting and within each primary ray usually only a single pseudo-verticillate whorl of umbellules below the terminal cluster. The flowers in Teijsmann 13687 are in particular similar to those depicted in Icones Bogorienses. While habitat and other field data are scant, Polyscias koordersii has been reported from open situations including grass-fern vegetation as well as forest, and has also been collected in village thickets. Most records are from 500-1600 m. The leaves reportedly are crowded together in palmoid crowns, leading to one collector dubbing Polyscias koordersii as a 'character-tree'. 
2. Polyscias papuana (Miq.) Seem., J. Bot. 3: 181 (1865). - Gastonia papuana Miq., Ann. Mus. Bot. Lugduno-Batavi 1: 5 (1863); Boerlage, Handl. 1: 647 (1890); Harms, Bot. Jahrb. Syst. 56: 408 (1921). - TYPE: [Indonesia, West Papua], New Guinea, [vicinity of Triton Bay, 1828], Zippelius s.n. (lectotype L, designated by Philipson, 1970b; isolectotype K [K000792800]).

What initially was Gastonia papuana was described from a single collection by Zippelius [sp. no. 191] from the vicinity of Lobo in Triton Bay with purportedly 7-12 free styles. Ostensibly complete material is in L and $\mathrm{K}$. The former includes two primary inflorescence branches bearing umbellules with immature fruits exhibiting 6-7 divergent styles (a third branch, on the right, appears to be from material of Polyscias paucidens); the latter, a leaf and one inflorescence branch. The leaflets are slightly obovate to elliptic and entire or nearly so, while the umbellules in the primary branches of the inflorescence may be pseudo-verticillate. Possibly the same is de Vogel 4229 (BO, L) from Obi in Maluku Utara with a distinctly 'Gastonia' fruit. In that collection the main axis is shorter than the primary branches while the latter may have only one subsidiary pseudo-whorl of 2 umbellules and a distinctly greater number of terminal umbellules. The maturing fruits have 7-8 largely free, radiating styles, and the source tree was $12 \mathrm{~m}$ tall and growing in nickeliferous soil. Phillipson 6427 (L, MO n.v.) and several other collections obtained since 2010 from Weda Bay in Halmahera can be of comparable stature and have similar fruit with 6-7 largely free styles and umbellules largely in pseudo-whorls but, as in de Vogel 4229, the peduncles are longer and, more uniquely, the leaflets are often acute. The Weda Bay collections have also been obtained from heavy metal habitats. Further collections are needed to more effectively establish the likely limits of this species but, in any case, the leaflets do not resemble those in Polyscias paucidens nor do the immature fruits. Potentially problematic, apart from finding populations, is that most individuals may not be flowering (Phillipson 6427). No similar material has been seen for Sunda west of Wallace's Line. In New Guinea, the most nearly similar collections are Vink \& Vink $B W 15261$ (CANB, K, L, LAE) and 15398 (BRI, K, L, LAE) from the Ayamaru Lakes although there the leaflets are more elongate and the styles more united into a column with but short free portions reminiscent of 'classical' Tetraplasandra.

3. Polyscias paucidens (Miq.) Frodin, comb. nov. - Tetraplasandra paucidens Miq., Ann. Mus. Bot. Lugduno-Batavi. 1: 4 (1863); Boerlage, Handl. 1: 650 (1890). TYPE: [Indonesia, Java,] Sunda Strait, Dwars in de Weg [P. Sangiang], ascribed to E.A. Forsten by Miquel and Philipson but in fact most likely obtained in 1823 by J.C. van Hasselt (lectotype L [L0008442], designated by Philipson, 1970b; possible isolectotypes L [L0008441, L0008443, L0008444]). The collection by Zippelius ('178a' in Philipson, 1970b) from New Guinea remains a syntype.

Miquel originally described Tetraplasandra paucidens from Sangiang Island (Dwars in de Weg) in the Sunda Strait and New Guinea. For Sangiang and elsewhere in Sunda can now be included three collections, respectively from Sangiang (as noted above), 
Enggano (Lütjeharms 4793, BO, K, L, US), where trees were recorded as $27 \mathrm{~m}$ tall with a clear bole of $11 \mathrm{~m}$, and Gunung Besar on Bawean Island [NE of Java] (Buwalda Ja.4235, BO [acc. no. 1444550] — newly recorded here) although in the last number the leaflets are thicker and the tree concerned was indicated as being no more than $5 \mathrm{~m}$ tall. The first of these was originally credited by Miquel to E.A. Forsten but, judging from the style of the label of 0008441, more likely it was obtained by J.C. van Hasselt on his tour of Sangiang in 1823. Three further sheets at L [L0008442, L0008443, L0008444], curatorially credited to 'Kuhl \& van Hasselt', may be part of the same gathering. Miquel in his protologue also included Zippelius s.n. [sp. no. 178a] from Lobo on Triton Bay in New Guinea, now represented in K [K000792799], L [L0008445, L0008446, L0008447, L.2567313 ex-GRO, U.1094711] and P [P04180983]. However, these show slight differences in venation and marginal dentation to the Sunda material. To these may be allied Hombron s.n. (P [P04180982, P04180985]) from Pulau Laut just southeast of Borneo and Hombron s.n. (P [P04180984, P04180986]) from Ambon, both with elongate main inflorescence axes (not represented in the earlier material). All appear to have a less developed stylopodium with no more than short stylar arms, indicative of Miquel's original inclusion of this species in Tetraplasandra. Early preanthesis inflorescences have small leafy bracts subtending the umbellules, but these are later fugacious. It may be that this is the most widely distributed of the segregates recognised here, but more records from between Sunda and New Guinea would be desirable. Similar to Zippelius's collection are Moll BW 9893 (BISH, BO, CANB, L, MAN) and 9909 (BISH, BO, CANB, L, MAN) from Adi Island in Papua Barat, with, however, in 9909 globose, almost 'tetraplasandroid' fruits where only a short length of the styles radiates from the stylopodium, and Teijsmann 08743 (BO, L) from Timor Barat, although in that number the leaflets are more elongate for their length and distinctly taper towards the apex. Also related may be Iboet 537 and McDonald \& Ismail 4324 from Sumba, but there the peduncles are longer than in the Sunda records of Polyscias paucidens.

4. Polyscias philippinensis (Merr.) Frodin, comb. nov. - Tetraplasandra philippinensis Merr., Philip. J. Sci., 1 (Suppl.): 219 (1906); Merr., Enum. 3: 222 (1923). - TYPE: Philippines, Palawan, Casuarina Point, near sea level, H.M. Curran FB 3809 (lectotype $\mathrm{K}$, designated here).

Polyscias philippinensis is characterised in particular by leaves with a variable number (up to 10) of pairs of pinnae, oblong-ovate to oblong leaflets with obscurely and coarsely crenate/serrate margins, and depressed-globose fruits 7-8 $\mathrm{mm}$ high with 7-10 pyrenes and only partially developed styles. The subsidiary umbellules are usually in pseudo-verticils along the axes of the primary branches. The stylopodium and degree of stylar development are more as in Tetraplasandra than Gastonia. Further study suggests that the leaflets do not match those in the type of Polyscias serratifolia. Initially collected from near beaches, the known records are from Palawan including the remaining syntype (Casuarina Point, Curran FB 3844 [K, L (barcode L.2567372), US]) along with the more recently collected Soejarto et al. 6191 (L, SING) from Tabon 
Island near Quezon. Similar to these is the earlier-mentioned Wong 2863 (K, L, SAN) but that appears to have larger leaflets along with scarcely developed styles in fruit. The number of carpels (and pyrenes) given for Polyscias philippinensis is comparable to that reported for the fruits of Gastonia winkleri Harms but there the stylar arms were said to be well-developed, placing it in 'classical' Gastonia.

5. Polyscias solomonensis (Philipson) Frodin, comb. nov. - Tetraplasandra solomonensis Philipson, Bull. Brit. Mus. (Nat. Hist.), Bot. 1: 11 (1951). - TYPE: Solomon Islands, San Cristoval [Makira], Hinuahaoro, 900 m, 16 September 1932, L.J. Brass 2866 (holotype A [A00073320, A00073321]; isotypes BISH [BISH1000828), BM [BM000810434, BO [old (and reused) acc. no. 105793], BRI [BRI.AQ-0215714], L [L.2567301]).

When first described, Polyscias solomonensis was noted for its being geographically distant from other then-recognised members of Tetraplasandra but in the protologue likened more to the species then accepted for Malesia than those in Hawai' $i$. It is characterised by a high foliar phyllotaxis with the leaves somewhat persisting, entire leaflets, subumbellate inflorescences with primary branches exceeding in length the main axis usually bearing a single subsidiary pseudo-verticil of umbellules, elongate peduncles, and fruits with 7-13 styles which, however, are only partially spreading from the stylopodium towards maturity and so resemble those in, for example, Henderson $S F 36272$ from the Pisang Islands in the Straits of Malacca. Two collections have been made since 1932 (Whitmore RSS 6315 in 1965 and Powell with Ramo BSIP 19390 in 1972). The high phyllotaxis is comparable to that in Lam 3262 from Karakelang in the Talaud Islands, but there the leaves are smaller and moreover relatively soon falling. I have no hesitation in reinstating this as part of Polyscias. It is reportedly associated with a so-far undescribed species of Gymnostoma (Casuarinaceae).

\section{Imperfectly known taxa}

1. Polyscias eupteronoides (Teijsm. \& Binn.) Frodin, comb. nov. - Gastonia eupteronoides Teijsm. \& Binn., Natuurk. Tijdschr. Nederl. Ind. 25: 416 (1863). TYPE: not so far identified, but a specimen collected by S. Kurz (BO) from KRI Bogor relates to, and is contemporary with, the protologue.

Gastonia eupteronoides was described from material cultivated in what is now Kebun Raya Indonesia, Bogor, from stock allegedly obtained by J.E. Teysmann from 'Sangian' (Sangiang or Dwars in de Weg) in the Sunda Strait between Java and Sumatra. Without discussion, Miquel (1863: 219) almost immediately reduced it to his Tetraplasandra paucidens, perhaps assuming that such a small island could not harbour two distinct species; but, other characters aside, Miquel's action crossed a then-accepted generic boundary. Gastonia eupteronoides was described as having 10-12 stigmata which 
in fruit were at the ends of 'exserted' styles, while in Tetraplasandra paucidens the stigmata were described as papillose within a more or less flat disk at anthesis, with afterwards the stylopodium developing and the fruits 7-8-locular but without mention of exserted styles. Examination of extant contemporary material of the two taxa in BO and $\mathrm{L}$ suggests that quite different plants are involved. The only named specimen of Gastonia eupteronoides (in BO) dates from the period 1859-63, the years when W. Sulpiz Kurz acted as an assistant to Teysmann and was responsible for the collections. It bears some resemblance to Teysmann 6015.H.B. (BO Acc. No. 1444930, with the H.B. number later rendered as ' 615 '), collected from 'Siam' but more likely from Bintang in the Riau Islands in 1860 on a stopover as part of Teysmann's voyage to Thailand (Van Steenis-Kruseman, 1950). The fruit in that number are partially developed, but as yet with little discrete stylar development; a similar situation obtains in nearlyripe fruits of Henderson SF 36272 from the Pisang Islands in the Straits of Malacca west of Johor. The leaflets in the two cited collections and as described for Gastonia eupteronoides are of a similar magnitude, although in Teysmann 6015.H.B. they are conduplicate, and all have, or are said to have, a stylopodium and stigmata more like that classically associated with Tetraplasandra than Gastonia.

2. Polyscias serratifolia (Miq.) Lowry \& G.M.Plunkett, P1. Diversity Evol. 128: 74 (2010). - Arthrophyllum serratifolium Miq., F1. Ned. Ind., Eerste Bijv.: 341 (1861); Harms, Naturl. Pflanzenfamilien, III, 8: 55 (1897). - Gastonia serratifolia (Miq.) Steenis ex Philipson, Fl. Males. I, 9: 68 (1979). - TYPE: J.E. Teysmann 1073.H.B. [coll. Diepenhorst], Siboga [now Sibolga], Sumatera Utara (lectotype U [U0112371], designated by Philipson (1979a: 68); isolectotype [fragments only], L [L0043198]).

Miquel described his Arthrophyllum serratifolium from sterile material, and it remained in that genus until, during revision of the family for Malesia undertaken by W.R. Philipson in the 1960s and 1970s, it was found not to be in Arthrophyllum but better included in Gastonia. As the epithet predated Gastonia papuana as adopted initially for the complex by Philipson (1970b), a new combination was published in Gastonia (Philipson, 1979a). The alternative approach to taxa taken here, along with the state of the available material - no further collections from at or near the type locality have been made since 1860 - suggests that Polyscias serratifolia s.s. is best treated as imperfectly known. The venation and margins of the leaflets do not effectively correlate with Sundaic material of Polyscias paucidens nor do their form and venation fit with Teysmann 11324.H.B. (BO, K, L) and 11324A.H.B. (L), respectively from the tributary of Sungai Tayan on the Kapuas River (Kalimantan Barat) and P. Karimata off Kalimantan Barat. In the two latter collections the leaflets are more narrowly elliptic rather than oblong-elliptic or oblong-ovate as in Polyscias serratifolia. Some similarity with the leaflets of Ari Keim 245 (BO) from P. Karimunjawa in the Java Sea north of Jepara (Central Java) exists but there the leaflets have somewhat ascending rather than spreading-ascending venation and, ultimately, they are proportionally narrower. No effective match is moreover possible with other geographically proximate collections: 
the fragmentary Teysmann 6015.H.B. (BO [acc. no. 1444930]), given as from 'Siam' but most likely from Bintang (Riau Islands), which has thick, conduplicately folded leaflets, and Henderson SF 36272 (K, L, LAE, P, SING) from P. Komudi in the Pisang group off the Malacca Strait coast of Johor in Malaysia, which has subentire, differently shaped leaflets and larger fruit than in Ari Keim 245 and in fact is more like Gastonia eupteronoides. For the present, however, and particularly in the lack of known reproductive parts Polyscias serratifolia s.s. is best seen as imperfectly known.

3. Polyscias winkleri (Harms) Frodin, comb. nov. - Gastonia winkleri Harms, Repert. Spec. Nov. Regni Veg. 15: 20 (1917). - TYPE: [Indonesia], 'Südost-Borneo', Kwaru [now Kuaro in Paser Regency, Kalimantan Timur], H. Winkler 3078 (holotype B, now lost; possibly also in WRSL but status not known).

Harms gave no distinguishing features apart from indicating that it was the first record for 'classical' Gastonia in Borneo (and the second for Malesia since Miquel described G. papuana). His placement of Gastonia winkleri, however, surely rested on his description of the fruit as being 5-7 mm long with a nearly flat disk, very short stylar column, and 6-10 radiating styles; the pedicels moreover inarticulate. The most nearly similar collection from Sunda in this regard is Henderson SF 36272 from the Pisang Islands in the Straits of Malacca off Johor but in Gastonia winkleri the leaflets are larger at up to 15 by $5 \mathrm{~cm}$ and papyraceous or chartaceous rather than coriaceous. While for the habitat Harms merely gave 'Buschwald', Kuaro — at least in 1908 — was on or near an estuarine river, Sungai Paser, flowing out past Tanahgrogot into Teluk Adang; thus a situation similar to the locality of Teijsmann 11324 H.B. on Sungai Tayan off the Kapuas in Kalimantan Barat is possible (other collections of Polyscias serratifolia s.l. from Borneo having so far all been collected on offshore islands). The nearest of these geographically, and in some respects morphologically similar, is the previouslymentioned Wong 2863 but there the fruits lack projecting stylar arms (and it is from an insular habitat). With no known authentic material extant, for now Polyscias winkleri is best viewed as imperfectly known.

DEDICATION AND ACKNOWLEDGMENTS. I would like to dedicate this study to those who have in particular sought a better overall understanding of plant and forest form and structure, notably E.J.H. Corner, F. Hallé and D.J. Mabberley.

This study would not have been possible without access to collections and the use of related facilities at a variety of herbaria over nearly half a century, and I thank all the directors and curators concerned for their hospitality, including the making of digital images of specimens where necessary. Particular thanks are due to the Royal Botanic Gardens, Kew, my professional home since 1993, as a member of staff until 2000 and thereafter an Honorary Research Associate. Amongst recent or emerging public information resources, I would also like to acknowledge the Global Biodiversity Information Facility (GBIF) and its contributing organisations for their considerable efforts in creating and bringing together a very wide range of digital resources which have greatly facilitated this research. 


\section{References}

Ballment, E.R., Smith, T.J., III \& Stoddart, J.A. (1988). Sibling species in the mangrove genus Ceriops (Rhizophoraceae), detected using biochemical genetics. Austral. Syst. Bot. 1(4): 391-397.

Beck, J., Ballesteros-Mejia, L., Nagel, P. \& Kitching, I.J. (2013). Online solutions and the 'Wallacean shortfall': what does GBIF contribute to our knowledge of species' ranges? Diversity and Distributions 19(8): 1043-1050.

Carr, G.W. (2006). Preliminary investigation of the Dianella Lam. ex Juss., Rhuacophila Blume and Hemerocallis L. (Hemerocallidaceae) flora of Mt Kinabalu, Sabah, Malaysia. Fairfield, Victoria, Australia: Ecology Australia.

Costello, A. \& Motley, T.J. (2007). Phylogenetics of the Tetraplasandra group (Araliaceae) inferred from ITS, 5S-NTS, and morphology. Syst. Bot. 32(2): 464-477.

Ehrlich, P.R. (2005). Twenty-first century systematics and the human predicament. Proc. Calif. Acad. Sci., ser. 4, vol. 56, suppl. 1: 130-148.

Forey, P.L. (2005). Naming the world: is there anything left of Linnaeus? Proc. Calif. Acad. Sci., ser. 4, vol. 56, suppl. 1: 182-195.

Gaiji, S., Chavan, V., Ariño, A.H., Otegui, J., Hobern, D., Sood, R. \& Robles, E. (2013). Content assessment of the primary biodiversity data published through GBIF network: status, challenges and potentials. Biodivers. Informatics 8(2): 94-172.

GBIF (Global Biodiversity Information Facility) (2019). GBIF Occurrence Download. https://www.gbif.org. Accessed at various times through May 2019.

Hyland, B.P.M., Whiffin, T., Christophel, D.C., Gray, B. \& Elick, R.W. (2003). Australian tropical rain forest plants: trees, shrubs and vines. Collingwood, Victoria: CSIRO Publishing. [2 CD-ROMs with user guide.]

Lowry, P.P., II \& Plunkett, G.M. (2010). Recircumscription of Polyscias (Araliaceae) to include six related genera, with a new infrageneric classification and a synopsis of species. $\mathrm{Pl}$. Diversity Evol. 128(1-2): 55-84.

Meier, R. \& Dikow, T. (2004). Significance of specimen databases from taxonomic revisions for estimating and mapping the global species diversity of invertebrates and repatriating reliable specimen data. Conservation Biol. 18(2): 478-488.

Morley, R.J. (2000). Origin and evolution of tropical rain forests. Chichester, UK: Wiley.

Philipson, W.R. (1970a). A redefinition of Gastonia and related genera (Araliaceae). Blumea 18: 497-505.

Philipson, W.R. (1970b). The Malesian species of Gastonia (Araliaceae). Blumea 18: 491-495.

Philipson, W.R. (1979a). Araliaceae 1. In: Van Steenis, C.G.G.J., et al. (eds) Flora Malesiana, ser. 1, vol. 9, pp. 1-105. Alphen aan den Rijn, The Netherlands: Sijthoff \& Noordhoff International Publishers.

Philipson, W.R. (1979b). Identification Lists of Malesian Specimens 59, Araliaceae, pp. 10961116. Leiden: Foundation Flora Malesiana.

Plunkett, G.M. \& Lowry, P.P., II (2010). Paraphyly and polyphyly in Polyscias sensu lato: molecular evidence and the case for recircumscribing the 'pinnate genera' of Araliaceae. Pl. Diversity Evol. 128(1-2): 23-54.

Roos, M.C. (1984). Gastonia. In: Van Balgooy, M.M.J. (ed.) Pacific Plant Areas, vol. 4, pp. 148-149, map 255. Leiden: Rijksherbarium.

Sheue, C.-R., Liu, H.-Y., Tsai, C.-C., Rashid, S.M.A., Yong, J.W.H. \& Yang, Y.-P. (2009). On the morphology and molecular basis of segregation of Ceriops zippeliana and $C$. decandra (Rhizophoraceae). Blumea 54(1-3): 220-227. 
Smith, A.C. (1978). A precursor to a new Flora of Fiji. Allertonia 1: 331-414.

Smith, A.C. (1979). Flora vitiensis nova, vol. 1. Lawai, Kauai, Hawai'i: Pacific Tropical Botanical Garden.

Van Steenis, C.G.G.J. (1957). Specific and infraspecific delimitation. In: Van Steenis, C.G.G.J. et al. (eds) Flora Malesiana, ser. 1, vol. 5, pp. clxvii-ccxxxiv. Jakarta: Noordhoff-Kolff.

Van Steenis-Kruseman, M.J. (1950). Malaysian plant collectors and collections: being a cyclopaedia of botanical exploration in Malaysia and a guide to the concerned literature up to the year 1950. In: Van Steenis, C.G.G.J. et al. (eds) Flora Malesiana, ser. 1, vol. 1, pp. 1-606. Jakarta: Noordhoff-Kolff.

Wheeler, Q.D. \& Platnick, N.I. (2000). The phylogenetic species concept (sensu Wheeler and Platnick). In: Wheeler, Q.D. \& Meier, R. (eds) Species concepts and phylogenetic theory, pp. 55-69. New York: Columbia University Press.

Winkler, H.J.P. (1914). Beiträge zur Kenntnis der Flora und Pflanzengeographie von Borneo, IV (Die Pflanzendecke Südost-Borneos). Bot. Jahrb. Syst. 50, suppl. [Engler-Festschr.]: 188-208.

Wong, K.M. \& Sugau, J.B. (1996). A revision of Fagraea (Loganiaceae) in Borneo, with notes on related Malesian species and 21 new species. Sandakania 8: 1-93.

Zachos, F.E. (2016). Species concepts in biology. Cham, Switzerland: Springer. 